\title{
AN EVALUATIVE STUDY OF THE EUROPEAN COMMISSION' REPORT ON "TELEVISION WITHOUT FRONTIERS"*
}

\author{
Araş. Gör, Bülent ÇAPLI \\ A.U. Basın Yayın Yüksek Okulu
}

\section{INTRODUCTION}

On July 14, 1984 the Commission of the European Communities published a substantial Green Paper on "the establishment of the common market for broadcasting, especially by satellite and cable". The Paper has been prepared in response to a resolution of the European Parliament of March 12, 1982 which asked "that outline rules should be drawn up on European radio and television broadcasting, inter alia with a view to protecting young people and establishing a code of practice for advertising at community level". ${ }^{1}$ On May 25, 1983, initial response to the parliamentary resolution, the Commission adopted its interim report on "Realities and Tendencies in European Television: Perspectives and Options". That report was mainly concerned with examining the scope for creating a European television channel. The Commission did not deal with the question of how the common market for the national television channel could be established. Examination of this question was presented in the Green Paper.

The goal of this research is to examine the 367-page document called the Green Paper. The descriptive research method has been utilized to analyze the Green Paper which has had and will have very important impacts on the existing broadcasting systems of the European Community member states.

For this reason the author has tried to contextualize the document. The critique of the paper is included in the last section of this descriptive essay.

" "Green Paper on the cstablishment of the common market for broadcasting. especially by satellite and cable".

1 George Wedell, "Television without frontiers? Some initial reflections on the Green Paper of the EEC Commission", EBU Review, Vol. XXXVI, No. 1, January 1985: 21. 


\section{THE GREEN PAPER.}

Threefold purpose of the Green Paper is stated in the Introduction Section, as:

... to demonstrate the importance of broadcasting (radio and television) for integration and in particular, for free democratic structure of the European Communities; to illustrate the significance of the Treat! establishing the European Economic Community (EEC Treati') for those responsible for producing, broadcasting and re-transmitting radio and television programmes and for those receiving such programmes; and to submit for public discussion the Comr ission's thinking on the approximation of the certain aspects of Member States' broadcasting and copyright Law before formal propo:als are sent to the European Parliament and to the Council...

Lord Lockfield, the Vics-President of the Commission explained the aim of the Paper, during a conference organized by the Institute of European Trade and Technology on the subject of Television and European Community, was to provide a light regulatory framework for European broadcasting in a way that would above all favour the development and integration of the European broadcasting market. ${ }^{2}$ Above all, the Commission tried to deal with the question of the responsibility which the European Community can caim to have in the broadcasting field. ${ }^{3}$ Commissioner Heinz Narjer touched on this question in a debate in the European Parliament on May 23. 1984, and he said, "the purpose of the paper is to... demonstrate the releiance and application of the Treaty of Rome to this field of activity in orler to set limits to the efforts of those lawyers who might try to deny us any powers to act on it."

In the Introduction sect on of the Paper, the Commission claims that contrary to what is widely imagined, the EEC Treaty applies not only to economic activities but, as a rule, also to all activities carried out for remuneration, regardless of whether they take place in the economic, social, cultural spheres (inclung in particular information, creative or artistic activities and entertainment)..$^{5}$ Thus, the Paper states "... the

2 Lord Cockfield, "The future o No. 6, November 1986: 8.

3 Wedell, 21-25.

4 Wedell, 21-25.

${ }^{5}$ The Commission of the European Communities. Television Without Frontiers (the Green Paper) (Luxembour; $;, 1 \subseteq(4), 20$. 
Treaty quarantees free movement within the Community for whatever goods and services they (Member States' nationals) supply."

Moreover, the Commission explains the ways of which the EEC Treaty encompasses broadcasting. After referring to Articles 59, 60,62 of the Treaty, the Paper concludes that the Treaty of Rome quarantees broadcasting the right to transmit or rely their signals to other Member States (freedom of Community-wide broadcasting). It also provides recipients in the other member state the opportunity to capture such signals (freedom of Community-wide broadcasting reception) and to include them in their own selection of broadcasting (freedom of community-wide choice of transmission) ${ }^{6}$

\section{PART ONE: TECHNICAL ASPECTS}

In the Part One, the Commission examines the technical aspects under four main subheadings: A. New Developments in the audio-visual field. B. Direct satellite television, C. Cable television and D. Relationship between satellite and cable broadcasting.

According to the directive, the rapid development of audio-visual techniques in the Community is regarded in all Member States as exceptionally important for the futurc co-existence of individuals and of nations. ${ }^{7}$ The Commission expresses its concern that internationalization of broadcasting to which cable television and direct broadcasting satellites (DBS) will lead, gives rise to serious legal problems. Also, in the Part One, the moves towards harmonizing the technical broadcasting norms for direct satellite television are explained. In the last section of the Part One, the satellite-transmission and cable-transmission systems are considered both complementary and advantageous. ${ }^{8}$

\section{PART TWO: CULTURAL AND SOCIAL ASPECTS}

In general, this part of the Paper attempts to show the "extraordinary" cultural, social and economic significance of radio and television. It refers to the Annex 1 which shows the number of people reached by the two media in the community. However, it points out that the bulk of television viewers, and a great many radio listeners, receive programs only from the country in which they live. It is argued that the new transmission

\footnotetext{
Green Paper, 20.

${ }^{7}$ Green Paper, 22.

${ }^{8}$ Green Paper, 25.
} 
and broadcasting techniquess will allow those in other Community regions also to be reached from other Member States, giving them access to a broad range of information, opinion and culture in the Community. ${ }^{9}$

The European Convention for the Protection of Human Rights and Fundamental Freedoms of 4 November 1950, the Universal Declaration of Human Rights, the Intermetional Covenant on Civil and Political Rights, and finally the Final Act 0 ? the Conference on Security and Cooperation in Europe are quoted in the Paper as human rights quarantees with regard to the freedom to exi]ress opinions (active freedom of information) and freedom to receive infurmation, from all the usual sources of access (passive freedom of infermiltion). According to the Commission "Both of these freedoms act as qialintees for cross-frontierbroadcasting."

The Commission reiter:tes the important role of television in developing and nutruring awareness of the rich variety of Europe's common cultural and historical heritagre. ${ }^{11}$ It also stresses the significant contribution of cross-frontiers radio and television for European unification. Here the European Parliament's call for a supranational approach to the dissemination of information is quoted, "European unification will only be achieved if Europeans want it. Europeans want it if there is such a thing as a European identity. A Exrojean identity will only develop if Europeans are adequately informed."12

In addition, the Commission believes that the opportunity of watching foreign television broadiast; (including European programs) could help understanding between peojles, deepen their knowledge of each others culture and development and contribute towards a more widespread European identity. ${ }^{13}$.

However, the Papes: touches on the frequent warnings about the dangers of the cultural ciom nation of one country by another. The Commission thinks that this is not a problem among Member States as the statistics provided in Annex 3 show that no Member States are predominant. However, most $o$ ? the films shown come from one single nonmember country - the USA The directive then states, "the creation of a common market for television production is thus one essential step if the dominance of the big American media corporations is to be balanced."14

\footnotetext{
Green Paper, 34.

10 Green Paper, 37.

1 Green Paper, 42.

12 Green Paper, 42.

13 Green Paper, 46.

${ }^{14}$ Green Paper, 47.
} 
The Commission, in the last section of the part Two, attempts to answer an important question for the Community in two-and-a-half pages, i.e. "... what effect the opening up of internal frontiers made possible by Community-wide broadcasting will have on viewers and on the content of broadcasts in the future." In In doing this, it offers two important predictions on the effects of cross-frontier broadcasting. One is that contrary to the common fear regarding the media revolution, the provision of cross-frontier broadcasting is unlikely to produce an increase in viewing and listening time. The other is that viewers and listeners are likely to learn to use greater judgement and to be more selective. ${ }^{16}$

\section{PART THREE: ECONOMIC ASPECTS}

Part Three starts with explaining the two reasons for realizing the so-called "action on broadcasting". First is the Community's brief to create a common market for this important "branch of the economy". Second is the desire to facilitate cross-frontier broadcasting in the Community and to exploit its integrating effects. In the same Part the Commission provides a cursory review of costs and financing possibilities for broadcasting in the community. ${ }^{17}$ The Paper states that the infrastructure costs of introducing new transmission techniques such as cable and direct satellite broadcasting will be met only in part and indirectly by the broadcasting organizations. It continues to say that from an economic angle, establishment of a common market for broadcasting does have implications that go far beyond the broadcasting sphere. As an advertising medium, broadcasting organizations help to stimulate sales of goods and services in many branches of the economy. The cross-frontier broadcasting of advertising promotes cost savings and increases in efficiency. Here, however, the Commission suggests that the economic aspects must not be overlooked of, from a cultural and social point of view, the role of broadcasting as a medium providing information, expression of opinions, education and entertainment is to be preserved. ${ }^{18}$

The key role of modern integrated communication networks in maintaining the competitiveness of the European Economy on international markets is stated to show the necessity for the development of technical infrastructure for the new transmission techniques. Moreover, the efficient communication networks are considered as the nervous systems of modern

is Green Paper, 48.

16 Green Paper, 49.

17 Green Paper, 51.

${ }^{18}$ Green Paper, 67. 
industrialized societies. ${ }^{19}$ The same point is repeated by the Commission in an another Green Parier| "on the Development of the Common Market for Telecommunications Seririces and Equipment", published in June 30, 1987. That Directive points 'ilat the critical influence of telecommunication systems on the "nervous system" of modern society. It continues to state, "information, exchanges of tnowledge, and communications are of vital importance in economic activity and in the halance of power in the World today". In sum, this Paper ijritiates a common thinking Process regarding the fundamental adjustment of the institutional and regulatory conditions which the telecommunicatioils sector now faces. In particular, the Commission calls for abolishing the national frontiers which are considered to hamper the development of a consistent communications system within the European Communit: $y^{20}$

\section{PART FOUR: LEGA], ASTECTS}

Part Four of the Paper jrovides a summary, country by country, of the structures of broadcasting in member states. The national regulations relevant to the applicability of the Treaty are provided in the same Part. The Commission makes an attempt to make each legal system "transparent" in order to obtain an overall picture of the Community's ten broadcasting systems and to cnable the laws to be compared in the other Parts of the Paper. The surmarized information on member countries' broadcasting systems (emphalsis on television) as of june 14, 1984, are as follows:

\section{Luxembourg:}

In Luxembourg, the broadcasting authority is a profit-making public limited conpariy which carries on business under the name of Radio-Tele-Luxemliourg (RTL).

Advertising is allowed within the limits determined by the government. There are no special provisions for passive cable broadcasting, for active cable broadcasting.".1

Italy:

The Public broadcasting authority - RAI is financed from subscription fees and adverticing. Under the 1975 Act advertising may not

${ }^{19}$ Green Paper, 52.

20 The Commission of the Eluropean Communities, Towards a Dynamic European Community (Green Paper) (Brussels, 1987), 1, 7.

${ }^{21}$ The Commission of the Nuropean Communities, Telovision Without Frontiers (Green Paper), (Luxamboure, 1954), 77, 78. 
exceed $5 \%$ of transmission time. As of 1981 there were 972 private local wireless transmitters, of which 562 broadcast television programs. As far as the retransmission of foreign television programs by any national or company of a Member State is concerned, as long as they obtain a licence from the Ministry for Posts and Telecommunication, they are free to do so. $^{22}$

\section{Netherlands:}

There are eight broadcasting organizations in Netherlands. A public-law foundation NOS deals primarily with cooperation between the broadcasting organizations. Some $25 \%$ of financing for the Dutch broadcasting system comes from advertising revenue and approximately $75 \%$ comes from licensing fees.

The relay of foreign programs by means of direct broadcast satellites within the country is free..$^{23}$

\section{Belgium:}

Broadcasting in Belgium is organized as a public service. The three institutions set up by law are RTBF, BRT and BRF. Advertising is prohibited.

Any national of a member state established in Belgium is entitled to apply for an authorization in order to start cable television services in Belgium. Broadcasts from foreign countries may be transmitted by the cable companies. ${ }^{24}$

\section{United Kingdom:}

In the United Kingdom broadcasting may be carried out only under a licence from the Home Secretary. The BBC and the IBA hold such a licence ănd concessions agreement with the Home Secretary. The two corporations are financed in different ways: the IBA from advertising revenues from the private sector, the $\mathrm{BBC}$ from a public tax on television sets.

The transmission of broadcasts by cable, like wireless broadcasting requires a licence from the Home Secretary. ${ }^{25}$

\section{Ireland:}

In Ireland, the minister for Posts and Telegraphs issues licences

\footnotetext{
22 Green Paper (1984), 79, 82.

${ }^{23}$ Green Paper, (1984), 83, 87.

24 Green Paper, (1984), 88, 92.

25 Green Paper, (1984), 93, 89.
} 
for broadcasting. Such a licence is held only by the RTE, the broadcasting authority. RTE is allowed to carry advertisements. It is financed from idvertising revenues and broadcasting licence fees. Cable television has also been made subject to licencing. ${ }^{26}$

\section{France:}

TDF - a public industrial commercial corporation which is completely free to adrninister its own affairs and finances - is responsible for broadcasting in li rance. TDF is funded primarily by payments made by the program companies, which are TF1, A2 and FR-3 (national) and twelve regional companies.

The 1982 Act empowers the authorities to authorize cable networks to retransmil programs picked up in France from other countries. $^{27}$

\section{Federal Republic of jermany:}

In Germany broadcesting is a public service. There are nine regional stations, EJi, $\mathrm{HR}, \mathrm{NDR}, \mathrm{RB}, \mathrm{SR}, \mathrm{SFB}, \mathrm{SDR}, \mathrm{SWF}$, and WDR. The eleven lander have also set up a tenth nationwide channel-ZDF. Licence fees are the main source of funds for these stations with adverticing second. Some lander inter-state contracts explicitly include cible transmission amongst the corporations activities. $^{28}$

\section{Denmark:}

In Denmark, Da:imarks Radio has the monopoly of broadcasting and neither carries iny advertising. DR is an independent public corporation. Its activities are largely financed (89\%) from licence fees. It also has the right to distribute radio and television programs via cable. ${ }^{23}$

\section{Greece:}

In Greece, broadcesing (radio and television, including cable transmission) is uncer the immediate control of the State. The monopoly has been sranted to ERT 1 and. 2. Both organizations are financed from alvertising revenues and broadcasting fees. ${ }^{30}$

${ }^{20}$ Green Paper, (1984), 100, 1ij2.

27 Green Paper, (1984), 103, 107.

28 Green Paper, (1984), 108, 111.

29 Green Paper, (1984), 112, 114.

30 Green Paper, (1984), 115, 118. 


\section{PART FIVE: FREEDOM TO PROVIDE SERVICES}

If broadcasting policy is to be relevant in the European Economic Community context, that policy has to concern the transmission of signals without let or hindrance across frontiers between member states. In radio, transfrontier broadcasting has been a matter of course for many years right across the world. Those countries which try to exclude foreign radio signals do so in the face both the technical possibilities and of the accepted international broadcasting convention that the air is freely accessible to all, subject to the International Telecommunication Union (ITU) regulations.

The position of television signals has up to the present been quite different. On the whole, television services have been regarded as national activities, governed by national legislation. Coverage areas in the main have been designed in such a way as to minimize overlap with the services of other countries. In several parts of Europe this has, of course, been difficult due to the close juxtaposition of countries. The Benelux area is one example. Switzerland, Austria and their neighbours constitute another.

Both satellite and cable technology are potentially no respecters of frontiers. If the community did not exist, no doubt some ad hoc arrangements would have to be made to endeavour the ordering of these developments. This is the substantial effort, in Part Five of the Green Paper, to maximize the implications of the Treaty of Rome for broadcasting, particularly in television.

For the purposes of free movement, the Commission defines the broadcasting as a service not as a good. In doing this, it refers to the European Court of Justice decision in the Sacchi case which concluded that in the absence of express provision to the contrary in the Treaty, a television signal must, by reason of its nature, be regarded as provision of services. ${ }^{31}$ In another case, the Court confirmed its opinion and added, "There is no reason to treat the transmission of such signals (television broadcast) by cable television any differently" ${ }^{32}$

The Green Paper follows the same line of argument and bases its consideration of the application of the Treaty to broadcasting oin the assumption that it is dealing with services rather than goods. Accordingly, the Commission concludes that the provisions of Title III of the Treaty which is titled "Free movement of persons, services and capital" have been applied to this issue.

31 Green Paper, (1984), 118.

32 Green Paper, (1984), 120. 
However, Article 60 of the Treaty confines the services with which the Treaty is concerned $t_{0}$ ":ervices normally provided for remuneration". The same article clarifies; thu! implication of the "services" which includes, activities of an industrial o: commercial character, and the activities of craftsmen and of the prcfess ions. The Commission makes all the necessary attempts to bring the television broadcasting within the frame-work of these service sectors if $i t$ is covered by the provisions of the Article $60 .{ }^{33}$ For this purpose, the Comn wsion refers to another decision of the Court which concludes:

the decisive fact is that television broadcasting is normally paid for, i.e. remunerated, in one way or another. The conclusion must therefore be that it is a service of a kind to which the Treaty applies, no matte: frorn. whom in any particular case payment may come or may not conse. ${ }^{34}$

In order to ascertain whother broadcasting is provided for remuneration within the meaning, of Article 60, the Green Paper makes reference to national provisions of th: Member States. ${ }^{25}$ Then, the Paper goes on to argue that, "television programs are remunerated in all member states. They are provided, either d rectly or indirectly, in return for payments made by citizens, accept:rig the services supplied by the organizations... or in return for payments. frum the advertisers, or in return for both types of remuneration." ${ }^{36}$ The Commission's reasoning includes both the public services and the commercial sectors of television broadcasting.

There then follow a discussion of the extent to with cross-frontier broadcasting is an integral espect of television, requiring freedom to operate across the boundaries. Tre Commission argues that since broadcasting is propagated through the ai.., it cannot follow country frontiers for both technical reasons and becausst: of natural laws. The signals spill over frontiers. By its very nature, therefore, broadcasting is a transfrontier activity. ${ }^{37}$ The Commission trereiore states that the transfrontier character of broadcasting makes Articie 59 applicable which requires that restrictions on freedom to provide :ervices within the Community shall be progressively abolished. Under Articles 59 and 62, protection is afforded to the free cross-frontier mover ent of broadcast as such, once it is broadcast and its reception is techniccilly possible on the other side of the internal frontier. The Paper stipulate; that the origin of the broadcast must be

\footnotetext{
33 Green Paper, (1984), 120.

34 Green Paper, (1984), 126.

35 Green Paper, (1884), 121.

36 Green Paper, (1984), 122.

37 Green Paper, (1984), 127.
} 
in one member state and its reception in another..$^{38}$ And it goes on, "Freedom of broadcasting cannot tolerate any protectionist restrictions on the providers and recipients of services. It requires, as a correlative to the dependence on cable, the guarantee that foreign programs will be receivable via the cable". ${ }^{39}$

On the other hand, the Commission accepts the kind of protectionist restrictions which are provided in Article 56, on grounds of public policy, public security or public health.

The Paper, in an effort to approximate the national laws on broadcasting claims,

"the legal barriers to an exchange of broadcasting services among the member states should already have been removed under directly applicable Community Law, which takes precedence over contrary national law. On the other hand, if the legal obstacles to the reception and retransmission of broadcasts from other member states are not deemed to fall under the prohibition in the Treaty, an approximation of law will become necessary. Indeed, it will be imperative". ${ }^{40}$

In brief, if the application of the free movement provisions of the Treaty to broadcasting, as proposed in the Green Paper, is sustained, this should in future render unnecessary bilateral negotiations on individual cases every time broadcasters from one member state want to send a signal for reception to another.

\section{PART SIX: HARMONIZATION OF LEGISLATION}

Part Six of the Green Paper deals with those elements of national legislation which have' to be brought into harmony in order to realize the freedom of movement of broadcasting services throughout the Community.

The areas in which it is proposed to work towards harmonization are: the Rules on Advertising; the Rules Governing Public Order and Safety Including the Protection of Minors and the Protection of Personal Rights; Copyright.

The Commission regards the harmonization proposals as a corollary of its insistence on the freedom to provide broadcasting services. Having

\footnotetext{
\$8 Green Paper, (1984), 128.

39 Green Paper, (1984), 135.

${ }^{40}$ Groen Paper, (1984), 153.
} 
proposed the suppression of discriminatory restrictions on the free movement of broadcasts the Commission here goes on to propose specific measures to govern cross-trontier broadcasting in such a way as to make it acceptable to all membear states.

The Green Paper provides a comparison of the legislation on radio and television advertisin!; of member states. Broadcast advertising is forbidden in Denmark: and Belgium. Other member states that allow advertising require the observance of rules regarding the following areas: ${ }^{41}$

a. In some member states, there must be a clear separation of - advertisement from the rest of the program.

b. Sponsor advertising is allowed on radio in Greece and Ireland, but it is prohibited on televisions of Germany, Greece, Ireland, Italy, Netherlainds and United Kingdom.

c. In many memiluer states advertising spots or breaks may only be inserted betwe the programs of the station, i.e. before or after but never during juograms.

d. Transmission tine is restricted in some member states.

e. Tobacco producis and alcoholic drinks are the two most important groups of: Jroducts which are covered by a specific ban or restrictions on koadcast advertising.

In the Paper, it is prof:osed that the Community should work towards a directive under Article; 57 and 66 of the Treaty of Rome which would establish minimum standa1 ds for advertising for use throughout the Community. From the survey of rules on broadcast advertising the Paper concludes that the differences in the law are substantial and that they at least tend to act as obstacles to cross-border broadcasting in the common market. ${ }^{42}$ The Commisision considers, however, that broadcasting should be authorized in all member states. To support this argument; the European Parliament's call ficr liroadcast advertising to be allowed everywhere in the Community is also stressed. The Green Paper considers advertisement important aspect since television advertising provides revenue on which broadcasting orianizations rely; it provides significant means for the stimulation of intelest in goods and services provided by industry and commerce; and it wan be useful means of informing consumers about the goods and services available to them. ${ }^{43}$

\footnotetext{
41 Green Paper, (1984), 223, 252.

42 Green Paper, (1984), 268.

43 Green Paper, (1884), 280.
} 
In order to arrive a common standard, the Green Paper proposes that the upper limit of advertising time should be $20 \%$ of total daily broadcasting time.4 This proposal not only seems excessive, but it is also out of line with the evidence contained in Annex 9 of the Green Paper itself. The maximum advertising time per day in the Annex ranges from nine minutes o nthe MTV/YLE II channel in Finland to 90 minutes on the ITV channel in the United Kingdom. But even ITV maximum represents only $10 \%$ of a total daily transmission time of 15 hours. Although the Green Paper says that it is generally accepted that consumers are not fundamentally hostile to broadcast advertising, present practice in European countries as reported in Annex 9, suggests that an increase to $20 \%$ might well exceed the tolerance treshold of most viewers. ${ }^{45}$.

The Commission makes a further assertation that advertising that is honest and fair is not only a service at the disposal of advertisers, but in general also represents a means of informing consumers, making it easier for them to meet their requirements in terms of goods and services. ${ }^{46}$

In sum, the Paper concludes that the severe limits on television advertising time are at present creating a bottleneck in the economic expansion of the branded goods industry and the advertising industry.

\section{THE CRITIQUE OF THE GREEN PAPER}

The Commission of European Communities has located a dilemna with this Paper. Its aim is the free flow of information and television programs through member states for political objectives which will provide substantial economic benefits. But it sees existing broadcasting organizations as a potential obstacle to the desire end..$^{47}$

On March 30, 1984 the European Parliament called upon the Commission to formulate rules to ensure that public broadcasting monopolies do not seek to prevent private broadcasters and program makers from fully contributing to the future developments. ${ }^{48}$ In fact, these organizations are considered as the main bastions of national culture.

As it is, the Commission seems to regard broadcasting as analogous to any other service. In broadcasting, however, the European tradition has

\footnotetext{
4 Green Paper, (1984), 284.

45 Green Paper, (1984), 280.

${ }^{46}$ Green Paper, (1984), 280.

17 Gareth Locksley, "Direct Broadcast Satellites, The Media-industiral complex in the UK and Europe", Telecommunications Policy, Volume 11, No. 2, June 1987: 201.

48 Green Paper, (1984), 288.
} 
always relied for much of its quality on the principle of public service which was at the origin of most broadcasting systems in the Community. George Wedell, the Director of the European Institute for the Media, commented on this issue and said, "the Commission, in the anxiety to keep broadcasting within the bounds of Jitle III of Part Two of the Treaty (Rome), seems to assume that the North. American model of wholly commercial broadcasting system is the one that the Community should, or will inevitably, fallow. "49 The Commission has also been accused of avoiding the discussion of broadcasting in the main sociocultural context into which it belongs. This has been caused by the fear that member states might insist on their cultural autonomy outside the scope of the Treaty. In fact, in one of the rare occasions when the Commission deals with the cultural aspects of cross-frontier broadcasting, it is asserted that the dialogue between different cultural and their interpenetration and crossfertilization, nurtured as they are by redio and television, do not pose a threat to a country's public policy but preserve it from isolation, onesidedness and nationalisin by imparting a European dimenson. ${ }^{50}$

The Green Paper supports Pan-European cultural integration together with providing allowance for individual national cultures. On the other hand, the West German 'Trade Union Organization, IG-Medien associating the majority of journalists and related cultural workers, in its published critical standpoint to the Paper, claimed:

In its present form these aims can not be achieved by the project (the Green Paper), as it is based on a market economy... (which) strives for economic profitability and lacks the means of preserving and elevating national and integrated cultural values. ${ }^{5 x}$

It is interesting to note: that European Commission does not justify its proposal simply by referring to protecting free flow of information. Instead the Commission while it is attemting to establish an European broadcasting system, is concerned with the free flow of information as a part of economic services. Because of the economic nature of the European Community, the European Conmission has no independent jurisdiction in the cultural field. It can only take action in brcadcasting if it defines broadcasting as an economic service rendered for some form of remuneration. Viewed from this angle, the desired "common market for broadcasting"

19 Wedell, 25.

so Green Paper, (1984), 150.

51 The International Journalism Institute, "Western Europe: Television Without Frontiers Project", Mass Communication Media in the World, Vol. IV, No. 3. March 20, 1987, 18. 
can be created if the barriers to an all European commercialization are removed. ${ }^{52}$

Riem argues that "the planned changes to the broadcasting system jeopardize national cultural values and traditions." It seems likely that commercialization of the broadcasting systems will lead to the loss of a tradition in broadcasting which has been of major significance in the cultural life of the member states. According to George Wedell this tradition has number of characteristics:

National public service organizations have provided in their radio and television services diversified and balanced programming for a wide range of groups in the population, including minorities whom commercial organizations would find it uneconomic to serve. The organizations have taken particular care to represent in their program patterns the various currents of opinion and of thought which are significant in their countries.

The Euromedia Research Group study published in 1986, shows that those public broadcasters forced to compete with commercial broadcasters also feel compelled to include more foreign productions with greater audience ratings potential. Still all European broadcasters import foreign in particular the U.S. productions. Wolfgang Hoffman-Riem claims that a communication order should contribute towards satisfying the needs of individual and society in an optional manner. ${ }^{53}$ But he admits that an exact specification of these communication needs however difficult. In fact, there is a common conviction in Western democracies that the diversity of communication content should be a major goal of any media system. It is very unfortunate that the Green Paper does not address the preservation of diversity of content.

The Public service philosophy of broadcasting, still actively supported in many European countries, is oriented toward the accessibility of pluralistic information for citizens and safety rather than the freedom of expression of communicators. This is the main reason why the national distribution systems of broadcasting are subject government regulations. Because broadcasting, during its early stages, was regarded by most European countries as cultural service and not a commercial product.

Whereas, in commercial broadcasting systems the production and distribution of programs are subject to market forces. A well known

\footnotetext{
52 Wolfgang Hoffman-Riem, "National Identity and Cultural Values: Broadcasting Safeguards", Journal of Broadcasting \& Electronic Media, Vol. 31, No. 1, Winter $1987,67$.

53 Riem, 60.
} 
phenomenon is that conmercial broadcaster prefers programs with mass appeal. Advertisers are interested primarily in the numbers watching programs and not consurner satisfaction gained from watching such programs. The commercial viability of a program in an advertiser-financed broadcasting system rnust mean that the program has to generate large enough numbers to inciuce advertisers to pay enough to cover the cost of showing program. As Riem puts it; "it would be mistaken to regard the freedom of mass communication primarily as the freedom of owners of large enterprises to commercialize their product, in this case, programs". ${ }^{4}$

\section{SELECTED LIST OF WORKS CONSULTED}

Cocfield, Lord. "The Future of television in Europe. "EBU Review, Vol. XXXVII, No. 6, November 1988: 8-13.

"Evolution of the European Community". Finance \& Development, September 1986: 30-31.

Hoffmann-Riem, Wolfgang. "National Identity and Cultural Values: Broadcasting Safeguards". Journal of Broadcasting \& Electronic Media, Vol. 31, No. 1, Winter 1987: 57-72

Locksley, Gareth. "Direct Broia,Acast Satellites". Telecommunication Policy, Vol. 11. No. 2, June 1987, 193-207.

Lopəz-Claros, Augusto. "The Ėuropean Community: On the Road to Integration". Finance \& Development. Sept. 1987: 35-38.

McKendrick, George G. "The INTUG view on the EEC Cireen Paper", Telecommunication Policy, Vol. 11, No. 2, Dec. 1987: 325-329.

McQuail, Denis, Karen Siune, eds. New Media Politics. Erristol: SAGE, 1986.

Pragriell, Anthony. Television in Europe. European Institute for the Media, Media Monograph, No. 5, 1985.

Solomon, J.H. "The EEC Green Paper, A faltering step in the right direction". Telecommunication Policy, Vol. 11, No. 2, Dec. 1987: 322-324.

The Commission of the European Communities, Television Without Frontiers IGreen Paper), (Luxembourg, 1984).

The Commission of the European Communities, Towards a Dynamic European Community (Green Paper), (Brussels, 1987).

Wedell, George. "Television Without Frontiers? Some initial reflections in the Green Paper of the EEC Commission". EBU Review, Vol, XXXVI, No. 1, January 1985: 21-25.

54 Riem, 69. 